\title{
Youth Unemployment and Peace in Nigerian Society
}

\section{Onah Nkechi G. Ph.D}

\author{
Department of Religion and Cultural Studies, University of Nigeria, Nsukka
}

Email: gloria.onah@unn.edu.ng

\section{Okwuosa Lawrence N. Ph.D}

Department of Religion and Cultural Studies, University of Nigeria, Nsukka

Email: Lawokwuosa@Libero.it

\section{Doi:10.5901/mjss.2016.v7n1s1p52}

\begin{abstract}
This article explores unemployment among the youths in Nigeria and its impact on peace and stability in the country. It draws data from National Bureau of statistics documents, books, journal articles, and other scholarly works. These were analyzed in order to re-evaluate the implication of unemployment among the youths in Nigeria and proffer solutions to the predicament. Findings revealed that the unemployment rate among the youths in Nigeria is high and worrisome despite the rich natural recourses in the country. It further indicates that youth unemployment is associated with high rate of violence and criminality in the country which have continued to jeopardize the peace and security of the nation. To reverse the trend of youth unemployment and ensure peace and security in Nigeria, the research suggests that the Nigerian government should set up more skill acquisition centres through effective entrepreneurship development, revitalize ailing industries, encourage agriculture, and fight corruption.
\end{abstract}

Keywords: Youth unemployment, peace, insecurity, development, Nigeria.

\section{Introduction}

Youths make up the active population of any society. The active population of any society is its productive sector and this determines to a large extent the level of development of that society. When the youths, being the active population, are made unproductive, consciously or unconsciously, that society tends to remain stagnant in her developmental strides. According to Anyanwu (2014:291) youth (aged 15-24) unemployment is currently one of the greatest global development challenges facing countries globally. Relating this to the African continent, he affirmed that Africa which has more than 60 percent of its population currently under the age of 25 , is the fastest growing and most youthful population in the world. With regards to Nigeria, unemployment among the youths is one of the major problems inhibiting the peace and security of the country.

The term youth varies from one country to the other. In Nigeria, youths are regarded as people between the ages of 18 and 35 years old (Second National Youth Policy Document of the Federal Republic of Nigeria 2009). The Ethiopian (CSA) defines youths as persons between the ages of 15 and 29 years (PSD Hub 2010). But for the purpose of this study the term youth follows the United Nations (2009) definition which sees persons within the age bracket 15-24 years as youths. People aged 25 years and above are therefore referred to as adults. In general, over 200 million Africans are now officially designated as youths (that is, aged 15 to 24) (Awogbenle and Iwuamadi 2010). Ojo, Alaka and Odozi (2014:12) observed that Nigeria has a youth population of eighty (80) million, representing 60 percent of the total population of the country. Sixty four (64) million of them are unemployed while one million six hundred thousand (1.6 million) are underemployed. According to the central bank of Nigeria (2003) as reported by Akintoye (2003) cited in Njoku and Ihugba (2011:3) the national unemployment rate rose from 4.3 percent in 1970 to 6.4 percent in 1980. The increase observed in the 1980 statistics was attributed to the depression in the Nigerian economy of the late 1970s. He further explained that between this period and 1986, the rate of unemployment fluctuated around 6.0 percent. On the other hand, Edukugho (2004) stated that youth unemployment moved from 4.3 percent in 1985 to 5.3 percent in 1986, then 7.0 percent in 1987. Trend analyses of unemployment in Nigeria showed that the rate has not been stable. Okafor (2012: 7614) citing the National Bureau of Statistics $(2009,2010)$ noted that the national unemployment rates for Nigeria between 2000 and 2009 indicated that the number of unemployed persons comprised 31.1\% in 2000; 13.6\% in 2001; 
$12.6 \%$ in $2002 ; 14.8 \%$ in $2003 ; 13.4 \%$ in $2004 ; 11.9 \%$ in $2005 ; 13.7 \%$ in $2006 ; 14.6 \%$ in $2007 ; 14.9 \%$ in 2008 and $19.7 \%$ in 2009. In addition the issue of unemployment in Nigeria varies according to age group and gender. Data from NBS (2010) revealed that unemployment is more among persons between ages 15-24 years where $41.6 \%$ were unemployed while the unemployment rate was 17\% for persons between 25-44 years. The National Bureau of Statistics (2011:9) reported that the national unemployment rate increased to 23.9 percent in 2011 compared to 21.1 percent in 2010 and 19.7 percent in 2009 . The rate was higher in the rural area (25.6\%) than in the urban area which was $17.1 \%$. An analysis of unemployment rate in Nigeria from 2003-2011 indicated that youth unemployment was much higher than national unemployment as shown in Fig 1 below.

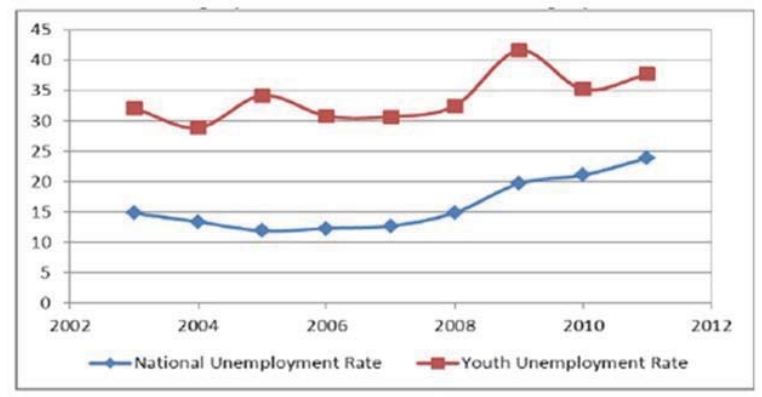

Figure 1: National Unemployment Rates and Youth Unemployment Rates, 2003-2011.

Source: National Bureau of Statistics (2012) cited in Alabi (2014: 303).

Yet it is acknowledged that Nigeria is blessed with rich human and natural recourses. With a population of 162.5 million people, Nigeria has the largest population in Africa (British Council/Ukaid 2012: i); and the 6th largest exporter among organization of Petroleum Exporting Countries (OPEC) members (Odeh 2011:87). With a GDP of \$502bn, Nigeria became the largest economy in Africa (Edet 2015) and 26th largest economy in the world (Enwegbara 2014). Paradoxically, unemployment continues to loom large in the country leading to poverty. In response to this situation, the Nigerian government at various times has made attempts to solve the problem by setting up various policies and programmes. Some of these include the National Directorate of Employment (NDE), the National Poverty Eradication Programme (NAPEP), and National Economic Empowerment and Development Strategy (NEEDs), However, these attempts have not made any significant impact on youth unemployment (Ugwu 2012). Thus, not denying the effort of the government in this regard, but based on the current situation in Nigeria, the paper aims to establish that youth unemployment is a major cause of the restive and violent situation confronting the country today. The paper also seeks to contribute to the ongoing debate and to advance the argument that unless the government tackles youth unemployment effectively there will be no enabling environment for socio-economic development in Nigeria. Therefore, there is the urgency for the government to intensify her effort to curb youth unemployment for peace and security of the country. The paper adopts a qualitative as well as quantitative analytical approach to situate the arguments. Data for the study were drawn from official documents, scholarly works, and news paper articles.

\section{Theoretical Framework}

The correlation between youth unemployment and security challenges in Nigeria can be better understood with the adoption of a theory known as the frustration-aggression theory. This theory is based on the premise that frustration causes aggression in any sphere of life. John Dollard et al (1939) proposed the Frustration-aggression theory. As Dollard et al proposed "aggression is always a consequence of frustration" and "frustration always leads to some kind of aggression". One cannot occur without another (Myers, 1993 in Mohammad and Omid, 2013 2013:3030).

In Nigeria, the youths comprise a very high percentage of unemployed persons and this has generated high rate of crime and violence in the society. Bilikis (2013) noted that "according to a recent World Bank statistics, youth unemployment rate is 38 per cent, but realistically, 80 per cent of Nigerian youths are unemployed with secondary schoolleavers mostly found among unemployed rural population ... the nation's universities and polytechnics continue to churn out more than 150,000 graduates annually and available jobs remain inadequate to keep pace with the ever-expanding army of job seekers." This predisposes them to nefarious activities. 


\section{Causes of Youth Unemployment in Nigeria}

There are factors that have been exacerbating youth unemployment rate in Nigeria. Reasons for unemployment among the youths in Nigeria are not too different from other causes of unemployment. Some of these factors include:

\subsection{High rate of population growth}

With the increase in population growth, Nigeria has a high number of youths thereby resulting in an increase in the size of the working age population (Folorunso et al 2010). Commenting further on that, Fowowe (2014) reported National Population Commission and ICF Macro (2009:3) as stating that, with the 2006 population census in Nigeria, the nation's population was estimated to be $140,431,790$ and projection for the future indicates that the population could be over 180 million by the year 2020, given an annual rate of 3.2 percent. Unfortunately, while the population is growing, there is no corresponding job opportunity for the youths. Thus, as the number of unemployed youths continues to increase and many of them have turned to hawking on the streets and highways as means to sustain them.

\subsection{The massive rural-urban migration}

Owing to the disinterestedness in agriculture and lack of basic infrastructure in the rural areas, so many young people have migrated to the urban areas with the hope of getting juicy jobs that are inexistent. In a similar view Okafor cited in Adesisna (2013) stated that lack of industries in the rural areas, pressure resulting from man-land ratio in the rural areas and seasonal cycle of climate contribute to the massive youth migration from the rural to the urban area which results in high unemployment rate among the youths in the country. Unfortunately, this upsurge of unemployed youths in the cities has resulted in rise of hoodlums who terrorize the urban dwellers.

\subsection{Dormant Agricultural System}

Many Nigerian youths are no more interested in agriculture. With the move to urban areas and crave for white collar jobs many youths are no longer interested in agricultural work because it portends being in the field, tilling the land and patiently waiting for the yields. Unfortunately, these are things which the youths are not ready for in the jet age of computer and technology. In accordance with this, Adesina (2013:149) argued that the agricultural sector which used to be the leading provider of employment in Nigeria especially in the sixties and in the seventies when the sector provided employment for more than 60 percent of the Nigerian population has been relegated to the background. This is as a result of the oil discovery, which created employment in the oil sector, leading to a large number of job seekers in the oil industry without even having the requisite credentials. At the same time, this situation undermined the agricultural sector only for the oil sector itself to be saturated thereby creating mega unemployment level in the country.

\subsection{Dearth of vocational and technical education}

There is decline in Vocational and Technical Education in Nigeria (Alhasan and Abdullahi, 2012). Vocational technical education trains the individual to develop occupational skills and become self-reliant. However, Nigeria has neglected Vocational and Technical Education to the extent that enrolment to these specialized schools has suffered a huge setback at secondary school level. More so, Colleges of Education and Polytechnics that should provide higher technical skills are neglected. University degree gained pre-eminence. Stressing on this, Dike (2009) noted that the image of technical education has since suffered as it is perceived as a program for academically unintelligent students who are only good at working with tools. He further stated that the nation's theory-oriented education and teaching method does not seem to satisfy the needs of the society. By implication, our education system seems to be producing job seekers instead of job creators.

\subsection{Fast expansion of the educational system}

The fast expansion of educational system is reflected in the number of tertiary institutions available in the country currently. Available statistics show that the total number of tertiary institutions in Nigeria was 402 in 2006, rose to 453 in 2010 (National Bureau of Statistics, 2011) and by 2013 it has increased to 469 (Ani, 2013). Similarly, the report of the Federal Ministry of Justice (2014:37) shows that over 1.37 million students were enrolled in universities, polytechnics and 
colleges of education in 2006 and another 1.98 million in 2007. Given that most courses are completed in 4 or 5 years, many of these 3.2 million students that enrolled in 2006 and 2007 would be entering the labour market in 2010/2011. These highlights do not include the number of Nigerians of working age that dropped out at secondary school level for various reasons and entered the job market in the rural and urban areas. With the current number of higher institutions in Nigeria, the number of people entering the labour market has exceeded the figure stated above. Hence, the demand for labour exceeds the supply. Nigerian government and other agencies have not been able to provide suitable employment for these graduates.

\subsection{Corruption}

The high rate of youth unemployment is traceable to corruption which has led to break down of infrastructures. Corruption is a big challenge to Nigeria's progress. Nigeria's endowment with natural resources has not translated to the well-being of the citizens. Corruption has spread to all the segments of the society crippling developmental process. The siphoning or looting of funds meant for building infrastructure and other developmental projects by some officials is a contributory factor to youth unemployment in the country which has resulted to too many untapped talents. Further more, corruption discourages foreign investors which lead to fewer job opportunities for the youths.

\subsection{Decline in the manufacturing sector}

The decline in the manufacturing sector has continued to pose a serious challenge to employment of the youths. Everyday experience shows that many of the commodities that were once manufactured in Nigeria like textiles, rice, petroleum products and ceramic wares are now been imported into the country from abroad on regular basis. According to Okafor (2011:364) there are over 800 collapsed industries in Nigeria and over 837 factories closed shops in 2009 with about half of the remaining operating firms have been classified as "ailing". This situation poses a great challenge to the survival of manufacturing in the country. He further reported that the southwest area, which comprises Oyo, Ogun, Osun, Ondo, Ekiti, Kogi and Kwara states, is the worst hit with almost 225 companies lost during the year. The Lagos area covering Ikeja, Apapa, Ikorodu and other industrial divisions in the state, followed closely with 214 manufacturing firms closing shop before the end of 2009.

\section{Implication of Youth Unemployment on Peace and Security in Nigeria}

Peace is a prerequisite for national development. Invariably, this should be the civil responsibility of every Nigerian citizen. Consequently, being the most active segment of the society, Nigerian youths should be formidable force in the growth of the country if well harnessed. Youth unemployment no doubt has implications for peace and overall development agenda of any country. Youth unemployment promotes political and social instability in the country. The unemployed not only suffer from poverty but it may take effect on their psyche. According to Nedeljikovic (2014) "being young and unemployed can lead to increase in the risk of poverty, deskilling and social exclusion as well as cause loss of motivation and mental health problem". Akwara et al. (2013) also noted that psychologically, the unemployed usually experiences trauma, anger, frustration, low self esteem, negative life satisfaction, unhappiness and mental disorder including depression and acute stress. Studies have shown that youth unemployment is associated with increase in drug and alcohol use as well as higher levels of crime among young people (Nedeljikovic 2014).

In Nigeria today, unemployed youths are the major threats to peace and security in the society. The phenomenon has led to an atmosphere of lawlessness, high crime rate, poverty and insecurity of lives and property. This is reflected in the nature of criminal activities pervading Nigeria today which includes kidnapping, armed robbery, militancy, oil bunkering, internet scam, car snatching, murder, cultism, abduction, rape, food and drug adulteration, drug trafficking and abuse, prostitution, burglary, human trafficking, political thugs, advanced fee fraud (419) and various forms of insurgency. There is no gainsaying that the violence situation in the country could discourage investors from investing in a society full of insecurity and uncertainty while the existing ones could decide to relocate to more secure countries. This is a big setback to the socio-economic development of Nigeria.

Though the Niger-Delta area is rich in oil, the high rate of violence and militancy in the area has been associated with youth unemployment. The issue of militancy in the Niger delta has made the Nigerian oil fields very dangerous and has increasingly become a major threat to the nation's main source of revenue. Nigeria has lost billions of dollars in oil revenue to the activities of the militants (Ekpu, 2007). The activities of the militants have created a state of insecurity, anomie and distortion of the value system of the communities of the region. There has been blood-letting, hostage-taking 
and sporadic shut-down of production facilities and panicky withdrawal of some foreign oil firms in the region (Inokoba and Imubua, 2010). This could be an expression of frustration and anger by the unemployed youths.

In many parts of the country, especially the Southern part, kidnapping for ransom is now a lucrative business and the unemployed youths are mainly responsible for it. In many cases the rich and/or their family members are the targets. According to Umejei (2010) available statistics show that in December 2009, the Police Affairs Minister, disclosed that 512 kidnap cases were recorded from January 2008 to June 2009. A rundown of the statistics indicates that Abia State took the lead with a total of 110 kidnap incidents. The report added that between July/September 2008 and July 2009, over 600 million was lost to kidnapping and bullion van/bank robbery. The kidnapping business is still ongoing in the country. In 2013 a former deputy governor of Anambra State was kidnapped and killed for failure by the family to pay 30 million naira ransom demanded by the kidnappers. The family allegedly brought only 5 million naira which angered the kidnappers and they killed him (Daily Sun 2014:7). Although many of them are being apprehended by the security agents, they obviously portend great danger to the peace and development of the Nigerian society.

The issue of Boko Haram insurgency in the Northern Nigeria has been attributed partly to poverty and unemployment (Aleyomi, 2012; Adesoji 2010). The activities of this group which started in 2009 have led to destruction of lives, property and jeopardizing peace and security of the country. Many Southerners who live in the North have relocated leaving their sources of livelihood, thereby exacerbating unemployment in the country. For example, the United Nation's building in Abuja was bombed which led to the death of 20 people. On $20^{\text {th }}$ January 2012 the Kano Police Headquarters and the Immigration Office were attacked with explosives leaving 186 people burnt to death (Adetoro, 2012:24). On April 14, 2014 the Boko Haram group abducted over 200 girls from Government Girls Secondary School in Chibok, Bornu State. While majority of them are still in their custody the school is still closed down. Boko Haram attack is almost a daily event as one hears reports of attacks in different parts of the North causing blood-shed. This is not only affecting peace and security in Nigeria but Africa and the global community at large.

\section{The Way Forward}

Youth unemployment has continued to mar the peace and security of Nigeria. There is urgent need for effective way of curbing youth unemployment to enable the youth channel their energy to a more positive lifestyle for a peaceful Nigerian society. In this respect the following recommendations are made:

1. The Federal government should encourage and revamp vocational and technical education in order to empower the youths with skills that will help them live a meaningful and productive life. Such schools should be adequately equipped to enable them serve the purpose for which they were established.

2. The government at all levels should encourage entrepreneurship by allowing interested entrepreneur to obtain soft loans without much collateral to enable them start off businesses. Entrepreneurship studies should also be part of the curriculum of secondary and tertiary institutions to enable them to be self-reliant.

3. The government and other investors should help to revitalize some collapsed and collapsing industries to help the unemployed. For example the Nigercem, Nkalagu, Iron Steel, Emene Enugu, Golden Guinea Brewery, Umuahia, Imo State Paint industry, Mbaise, Nigeria textile industry, Nigerian Peoples bank etc. This will help in creating job opportunities for the teeming youths.

4. Even though the Ministry of Agriculture is making some progress in the agricultural sector, the effort should not be limited to government procuring machines and tools for the big mechanized farmers but also for the rural farmers who make up the greater population of Nigerian farmers. Government should establish model farms in the rural areas that will be a kind of resource centres for rural farmers.

5. Improvement on infrastructure both in the urban and rural areas. Infrastructure is part of development. The government should provide good roads, pipe borne water, constant power supply, good hospitals, and good schools to curtail rural-urban migration of the youths.

6. The Nigerian government should fight corruption with all seriousness. Corruption has marred several developmental projects that could help employ the youths for them to contribute their quota to national development.

7. All establishments, both national and multinational, should take their social corporate responsibility serious. They should all get involved in curbing youth unemployment by providing training programs, workshops and entrepreneurial education for the youths. This will provide them with the needed skills that will make them selfreliant. 


\section{Conclusion}

It is evident from statistics that a high number of the Nigerian youths are unemployed or under-employed. This is disheartening knowing the fact that Nigeria is a rich country both in human and material resources. The youths should be the drivers of the economy if given the opportunity. Youth unemployment has resulted in incessant crime such as kidnapping, armed robbery, militancy, oil bunkering, internet scam, car snatching, prostitution, murder, cultism, abduction, rape, drug trafficking and abuse, among other social vices. The youths engage in these nefarious activities as way to make ends meet and in a way to protest their ill-treatment by the society. This has resulted in breach of peace and security of the nation and consequently growth of the country. No country thrives in an atmosphere of insecurity and instability. A peaceful country attracts investors and investment creates job opportunities. Several reasons have been attributed to why unemployment rate is high. These include high rate of population growth, massive rural-urban migration, dearth of Vocational and Technical Education, neglect of agriculture, corruption etc. These notwithstanding, youth unemployment could be curbed through improving on infrastructure both in the urban and rural areas, revitalization of some collapsed industries, allocating more money to education sector, encouraging entrepreneurship, establishing more vocational and technical schools, encouraging agriculture and fighting corruption. To this effect concerted effort must be made by all stakeholders such as the government at all levels, national and multinational organizations to curb youth unemployment for peace and security of Nigeria, Africa and the global community.

\section{References}

Adesina, O. S. (2013). Unemployment and security challenges in Nigeria. International Journal of Humanities and Social Science (3), 7 , 146-156 [Online] Available: www.ijhssnet.com/journals/ (September 23, 2015).

Adesoji, A. (2010). The Boko Haram Uprising and Islamic Revivalism in Nigeria. Africa Spectrum, 45, 2, 95-108, [Online] Available: www.africa-spectrum.org (January 7, 2013).

Adetoro, R.A. (2012). Boko Haram insurgency in Nigeria as a symptom of poverty and political alienation. IOSR Journal of Humanities and Social Sciences (JHSS), (3), 5, 21-26.

Akwara, A.F., Akwara, N.F. Enwuchola, J., Adekunle, M. \& Udaw, J. E. (2013). Unemployment and Poverty: Implications for National Security and Good Governance in Nigeria. International Journal of Public Administration and Management Research, (2), 1, 1-11. [Online] Available: http;//www.rcmss.com (September 24, 2015).

Alabi, T. (2014). Youths' Unemployment and Crime control: An analysis of Nigerian Experience. European Scientific Journal, (10), 2 , 301-312.

Aleyomi, M. B. (2012). Ethno-religious crisis as a threat to the Stability of Nigeria's federalism. Journal of Sustainable Development in Africa, (14), 3, 127-140.

Alhasan, N. U. and Abdullahi T. (2012). Revitalizing Technical and Vocational Education (TVET) for Youth Empowerment and Sustainable Development. Journal of Educational and Social Research, (3) 4,149-154.

Ani, C.I. (2013), Enhancing Educational opportunities and National Development. Key note address presented at maiden conference of the Department of continuing education, Federal College of Education Eha-amufu Enugu State, June, 25-28.

Anyanwu ,J. C. (2014). Does intra-African Trade Reduce Youth Unemployment in Africa, in: African Development Review, (26), 2, 286309.

Aremu, M.A. and Ahmed Y. A. (2011), An Investigation of Security and Crime Management in Developing Society: The Implications for Nigeria Democratic Set-Up. Int. J. Acad. Res. Bus. Soc. Sci. (3), 1, 390-399.

Awogbenle, A.C. and Iwuamadi K.C. (2010). Youth Unemployment: Entrepreneurship Development Programme as an Intervention Mechanism. African Journal of Business Management, (4), 6, 831-835.

Bilikis, B. (2013), Addressing Youth Unemployment in Nigeria, [Online] Available: http://www.punchng.com/opinion/addressing-youthunemployment-in-nigeria/ (June 24, 2014).

British Council/Ukaid 2012), Gender in Nigeria Report 2012. Improving the lives of Girls and Women in Nigeria. Issues, Policies Action 2nd Edition.

Dike, V.E. (2009), Addressing Youth Unemployment and Poverty in Nigeria: A call for action, not rhetoric. Journal of Sustainable Development in Africa, (11), 3, 129-151.

Edet, L. I. (2015), The Paradox of Economic growth without development in Nigeria. IOSR Journal of Humanities and Social Science (20), 5, 64-77 [Online] Available: www.iosrjournals.org (September 21, 2015).

Edukugho, E. (2004), UNESCO tackles decline in technical, vocational education. The Vanguard November 25.

Ekpu, R. (2007), The dilemma of Niger Delta, in: Newswatch, August $13^{\text {th }}$ p 10-30.

Enwegbara, O. (2014) Is Nigeria really Africa's largest economy? [Online] Available: The Punch April 13 http://www.punchng.com/ business/global-finance/is-nigeria-really-africas-largest-economy/(June 20, 2014).

Federal Government of Nigeria (2009). Second National Youth Policy Document, [Online] Available:http://planipolis.iiep.unesco.org/ upload/Youth/Nigeria/Nigeria_Youthpolicy.pd (June 21, 2014).

Federal Ministry of Justice (2014). The Nigeria's $5^{\text {th }}$ Periodic Country Report: 2011-204 on The Implementation of the African Charter on 
Human and People's Rights in Nigeria. Federal Republic of Nigeria. [Online] Available: www.achpr.org (September 23, 2015).

Folorunso, O., Akinwale A. T., Asiribo, O. E. and Adeyemo, T. A. (2010). Population prediction using artificial neural network. African Journal of Mathematics and Computer Science Research (3), 8, 155-162. [Online] http://www.academicjournals.org/AJMCSR (September 21, 2015).

Fowowe, L. A. (2014). Financing entrepreneurship for youth empowerment in Nigeria - A panacea for unemployment. Proceedings of the 2011 International Conference on Sustainability of Political, Economic \& Educational Systems in Developing Countries. [Online] www.academia.edu (September 22, 2015).

Inokoba, P.K. and Imubua D.L. ( 2010). Vexation and militancy in the Niger Delta: The way forward, in: J. Hum Ecol, (29), 2,101-120.

Mohammad , M. R. and Omid. (2013). Does Frustration Cause Aggression? Case study: soccer fans in Iran. International Research Journal of Applied and Basic Sciences, (4), 10, 3028-3035.

National Bureau of Statistics. (2009). Social Statistics in Nigeria. Abuja: The NBS Publication.

National Bureau of Statistics. (2010). Statistical News: Labor Force Statistics No. 476. Abuja: The NBS Publication

National Bureau of Statistics. (2011). 2011 Annual Socio-Economic Report. [Online] Available: resourcedat.com (September 21, 2015).

Nedeljikovic, V. (2014). Consequences of high youth unemployment. [Online] Available: http://www.bridgingeurope.net/consequences-ofhigh-youth- unemployment.html ( June 6, 2015).

Njoku A and Ihugba $O$ (2011). Unemployment and Nigerian Economic Growth, Proceedings of the 2011 International Conference on Teaching, Learning and Change. [Online] Available: www. hrmars.com (September 21, 2015).

Odeh, M. A. (2011). Deregulation policy in the downstream oil sector and the Nigerian economy, Journal of Social Science and Public Policy, (3), 87-100.

Ojo, L. B., Alaka A. B and Odozi A. F. (2014). Entrepreneurship Education: A Viable Tool for Youth Empowerment in Nigeria, Academic Journal of Interdisciplinary Studies, (3) 4, 11-20. [Online] Available: www. mcser.org (September 21, 2015).

Okafor, E.E. (2011). Youth Unemployment and Implications for Stability of Democracy in Nigeria. Journal of Sustainable Development in Africa, (13) 1, 358-373 [Online].Available: www.jsd-africa.com/jsdal (September 23, 2015).

Okafor, E.E. (2012). Emerging nonstandard employment relations and implications for human resource management functions in Nigeria. African Journal of Business Management, (6) 26, 7612-7621. [Online] Available: http://www.academicjournals.org/AJBM (September 21, 2015).

PSD/Addis Ababa Chamber of Commerce and Sectoral Association (2010). Enabling the Private Sector to Contribute to the Reduction of Urban Youth Unemployment, Ethiopia.

Ugwu C. E. (2012). The subsidy Reinvestment and empowerment (SURE) Programme Implementation in Nigeria: Potentials for National Youth Unemployment Reduction, in: International of Research in Arts and Social Sciences 4, 375-389.

Umejei, E. (2010). Kidnapping in 'Kidnapped' Economy [Analysis]. Africa News Service. [Online] Available: Emekaumejei's Weblog (September 23, 2015). 